\title{
Measuring the relationship between career, guidance, and adults' training needs: Analysis and assessment of results from the perspective of the social responsibility*
}

\section{Evaluación de la relación entre carrera, orientación y necesidades de formación en adultos: Análisis y evaluación de resultados desde la perspectiva de la responsabilidad social}

\author{
Enrique Merino Tejedor** \\ Universidad de Valladolid, España \\ Susana Lucas Mangas*** \\ Universidad de Valladolid, España \\ Jesús Boyano Sierra**** \\ Universidad de Valladolid, España
}

\begin{tabular}{|c|c|c|}
\hline $\begin{array}{l}\text { **Psychology } \\
\text { enrique.merino@uv }\end{array}$ & $\begin{array}{l}\text { Department. } \\
\text { va.es }\end{array}$ & E-mail: \\
\hline $\begin{array}{l}\text { **Psychology } \\
\text { sulum@psi.uva.es }\end{array}$ & Department.. & E-mail: \\
\hline $\begin{array}{l}\text { *Department } \\
\text { jesusboyano@hotn }\end{array}$ & $\begin{array}{l}\text { Sociology } \\
\text { ail.com }\end{array}$ & E-mail: \\
\hline
\end{tabular}

\begin{abstract}
The aim of this paper was to analyze the training needs and career guidance, as well as the guidance received in the adult population in the Spanish region of Castile and Leon. This work is part of the R \& D project "The orientation of the vital and professional project in adulthood: Needs analysis, assessment of employment services and identification of best practices". Currently, the importance of vocational dimension in personal and social welfare is now recognized. The sample consisted of 375 subjects, mostly unemployed or in a position to improve their employment situation. Through the SPSS version 20 program, data corresponding to the descriptive statistics were obtained, as well as reliability values obtained by Cronbach's alpha coefficient, the correlation analysis, and the ANOVA findings. The results showed a positive relationship between the satisfaction with the career followed and the content of training. In addition, it was found that the importance of training content fits the profile of the participants in the training process. Subjects with a lower level of studies showed significant differences in training needs in relation to subjects with higher education.
\end{abstract}

Keywords

career, life projects, training needs, counseling services.

\section{RESUMEN}

En este trabajo se analizan las necesidades de formación y orientación de la carrera, así como la orientación recibida en la población adulta en la región española de Castilla y León. Este trabajo se enmarca en el proyecto I+D titulado "La orientación del proyecto vital y profesional en la edad adulta: Análisis de necesidades, valoración de servicios para el empleo e identificación de buenas prácticas". Actualmente se reconoce la importancia de la dimensión profesional en el bienestar personal y social. Participaron 375 sujetos, mayoritariamente en paro o bien en situación 
Enrique Merino Tejedor, Susana Lucas Mangas, Jesús Boyano Sierra.

de mejora de su situación laboral. Mediante la aplicación del programa SPSS versión 20, se obtuvieron datos correspondientes a los estadísticos descriptivos, los valores de fiabilidad obtenidos mediante el coeficiente alpha de Cronbach, así como los análisis de correlaciones y ANOVA. Los resultados mostraron una relación positiva entre la satisfacción con la carrera seguida y el contenido de la formación. Además, se encontró que la importancia del contenido de la formación encaja con el perfil de los participantes en el proceso formativo. Los sujetos con un nivel de estudios más bajo mostraron diferencias significativas en las necesidades de formación en relación con los sujetos con estudios superiores.

Palabras clave

carrera, proyectos vitales, necesidades de formación, servicios de orientación.

Para citar este artículo: Merino Tejedor, E., Lucas Mangas, S., \& Boyano Sierra, J. (2016). Measuring the relationship between career, guidance, and adults' training needs: Analysis and assessment of results from the perspective of the social responsibility. Universitas $\begin{array}{lll}\text { Psychologica, } & 15 & \text { (4). }\end{array}$ http://dx.doi. org/10.11144/Javeriana.upsy15-4.mrcg

The results presented in this study are part of the larger project: "The orientation of the vital and professional project in adulthood: Analysis of needs, assessment of employment services, and identification of best practices" 1 , which aims to analyze the needs related to the orientation of the vital and professional project in adulthood and to assess official guidance services for employment.

Career development plays a special role in people's life project, as shown by several authors from various perspectives (Bernal \& Donoso, 2016; Chen, 2010; Guichard, Pouyaud, \& Dumora, 2010; Lucas, 2012; McMahon \& Watson, 2010; Steger \& Dik, 2009). Moreover, in uncertain environments where access to employment is difficult, personal, social, and environmental wellbeing becomes much more dependent on one's job situation from the standpoint of social responsibility (Bernal \& Donoso, 2016; Lucas, 2012; Osorio, 2014). In these types of situations, career guidance for adults is particularly relevant, especially during economic downturns like the one we are currently undergoing, when getting and keeping a job has a special meaning, become a thorny issue, and leads to uncertainty among workers.

Numerous studies have shown the benefits of social participation in training and guidance in career development. It contributes to the development of personal identity from the commitment and solidarity instruments such as improving reality and fostering new opportunities. Career development throughout life can generate, at the same time, social dynamism (Martín, Lucas, \& Musitu, 2015).

In the field of career guidance, many studies highlight the relevance of career decision making (Bernal \& Donoso, 2016; Little, 2006; Lucas \& Carbonero, 2002; Mitchell, Levin, \& Krumboltz, 1999; Osorio, 2014; Romero, 2004; Savickas, 1997; Savickas et al., 2009). It is a subject of interest for career development researchers from the standpoint of social responsibility. These studies contribute to the construction of career development models based on sustainable, socially responsible, and personal development (Lucas, 2009, 2012; Martín, Lucas, \& Musitu, 2015).

The Universal Declaration of Human Rights is considered a prioritary international reference axis, in Article 23 includes the access to work as a universal right. Related to these issues and in accordance with the Recommendation of the European Parliament, the Council of December 18, 2006 on key competences for lifelong learning (2006/962/EC), and with the Unesco World Conference for Higher Education (1998, 2009), the development of a career project is related to adequate training and guidance as part of a lifelong learning process. In western societies, official counseling services are crucial in helping people develop their own professional projects in balance with social, economic, and environmental development. More specifically, they should be aimed at:

1. Describing the relationship between the satisfaction with the career path 
Measuring the relationship between career, guidance, and adults' training needs: Analysis and...

followed and the perceptions of counseling needs.

2. Identifying the relationship between the level of satisfaction with one's career path and the counseling process.

3. Deciding whether there is differential assessment of counseling when there is balance with the profile of the participant in the learning process.

4. Analyzing the differences in learning/ counseling needs regarding the educational background.

These goals give rise to a series of hypotheses underlying this study: (1) significant and positive relationships will be found between satisfaction and career path, counseling needs, and counseling process; (2) significant, positive and balanced relationships will be found between global level of satisfaction and training/ counseling, and participant's profile; (3) finally, positive correlations will be found between academic background and training/counseling needs.

Thus, the purpose of this research emerges from the interaction between personal project, career project, and counseling needs, making connections between satisfaction with career path and the training provided by official employment counseling services.

Following Zapata's research design (2005), and Martín et al. (2015), this educational and social research project takes on a critical approach in order to understand the richness and complexity of subjectivity in its social, cultural, and economic context.

It becomes essential to carry out this study from the mentioned theoretical framework in order to explore the dimensions or linked variables that are present in the training and guidance for career development; particularly, from narratives based on the concept and experience of the professionals involved in counseling and training of unemployed people or improving their employment situation, especially with vulnerable groups facing employment.

\section{Method}

\section{Participants and procedure}

Contacts were made with organisations in the Spanish region of Castile and Leon that were offering career guidance and training programs for adults. Their staff gave the survey to the users. An online version was also supplied, as it was easier to send to those users who had already finished their training activities.

The sample used for this survey consisted of 374 adults, $90.4 \%$ of them being Spanish citizens. The participant sample is part of a wide range of organizations and entities, public and private, following training and guidance programs. These organizations collaborate with the $\mathrm{R} \& \mathrm{D}$ project of this research and they are representative of the autonomous region of Castile and Leon.

All subjects were either unemployed or seeking to improve their work situation. The sample was made up as follows: $8 \%$ of the participants were from the Self-Employed Workers Association (ATA); 33.5\% came from Employment and Local Rural Development Agencies (AEDLs); 33\% were from NGOs offering counseling and training services to people at risk of poverty or social exclusion; $10 \%$, from employment workshops; $4 \%$, from the Public Employment Service of Castile and Leon; $4.5 \%$, from UGT-FOREM; and 7\%, from other services.

Regarding the gender, participants included 208 women (55.9\%) and 164 men (44.1\%), all of them aged 18 to 62 (average age: 36). Regarding educational background, $45.3 \%$ held university degrees, $25.3 \%$ had post-compulsory education, $24 \%$ had finished compulsory education and only $5.4 \%$ had no formal learning. Most of them came from urban and semi-urban environments ( $70.2 \%$ and $7.8 \%$, respectively), while only 82 participants $(22 \%)$ came from rural environments.

Finally, considering the reasons for seeking counseling, a wide majority $(78.4 \%)$ said they were looking for a job, while only $14.2 \%$ wanted 
to improve their current job prospects, and $7.4 \%$ had other reasons. As to the moment of the training programme they were in, $23.6 \%$ were just beginning, $43.2 \%$ had finished their training activities, and $33.1 \%$ were in the middle of the process. With regard to the work situation, more than half of the participants $(52.2 \%)$ were unemployed, $30 \%$ were employees, $8.7 \%$ were self-employed, only $2.2 \%$ were employed without a contract, and $7.1 \%$ had other work situations. $65.5 \%$ of the subjects had no dependants. Finally, participants had 11 hours a week on average for training activities, the highest number of hours available being 40 .

The results of the survey were analysed with SPSS v.20 software, focusing on descriptive statistics, correlation analysis data, as well as ANOVA analysis in order to test the differences between groups. Besides, Games-Howell and Tukey procedures were carried out to get an accurate notion of the differences.

The methodology is adapted to the ethical principles of anonymity of the participants and the results obtained were used to evaluate the objectives of the study and with the purpose of improving the socio-economic and educational standards of the population.

\section{Instruments}

The survey's psychometric properties were analysed by Padilla-Carmona, Sánchez-García and Suárez-Ortega (2013) for a sample of 1,816 participants, Cronbach's alpha being 0.94 and the factorial structure being consistent with the theoretical structure, with three factors accounting for $54.83 \%$ variance. The aspects under study are described below.

\section{General level of satisfaction with career path}

It was assessed with a single question: How satisfied are you with your career path as a whole so far? The answers were rated in a Likerttype scale, ranging from 0 (Not satisfied at all) to 5 (Very satisfied).

\section{Correlation between educational background and profile}

This aspect was evaluated with this question: How much do you think your educational background corresponds to your professional profile? The answers were rated in a Likert-type scale, ranging from 0 (No correlation at all) to 5 (High level of correlation).

\section{General satisfaction with educational background}

The following question was used for this aspect: How satisfied are you with your educational background and training so far (including both formal education and informal learning)? The answers were rated in a Likert-type scale, ranging from 0 (Not satisfied at all) to 5 (Very satisfied).

\section{Counseling needs}

The tool to assess this variable comprised 24 items with answers rated in a Likert-type scale, from 0 (I strongly disagree) to 5 (I strongly agree). An example of item is: I am able to set realistic professional goals for myself. In this scale the higher the scores, the lower the needs.

\section{Lifelong guidance process}

The tool used to evaluate this variable, included 19 items, answered in a Likert-type scale from 0 (I strongly disagree) to 5 (I strongly agree ). Example of item: The lenght of the counseling program is adequate.

\section{Results}

Table 1 shows the descriptive statistics of the variables considered, as well as the reliability data obtained with Cronbach's alpha. Both, the counseling needs and the counseling process questionnaires have optimal coefficients of 
internal consistence, namely, 0.94 and 0.92 , respectively.

\section{Table 1}

Descriptive statistics and Cronbach's alpha values of reliability

\begin{tabular}{|c|c|c|c|c|c|c|}
\hline & $\mathrm{N}$ & Minimum & Maximum & Mean & s.d. & alpha \\
\hline 1. Career satisfaction & 371 & 0 & 5 & 2.70 & 1.13 & - \\
\hline $\begin{array}{l}\text { 2. Education-profile } \\
\text { setting }\end{array}$ & 312 & 0 & 5 & 3.21 & 1.16 & - \\
\hline $\begin{array}{l}\text { 3. Global satisfacción } \\
\text { with education }\end{array}$ & 346 & 0 & 5 & 3.29 & 1.02 & - \\
\hline 4. Guidance needs & 331 & 12 & 118 & 83.11 & 16.13 & 0.94 \\
\hline $\begin{array}{l}\text { 5. Orientation process } \\
\text { followed }\end{array}$ & 309 & 5 & 65 & 45,80 & 11.49 & 0.92 \\
\hline
\end{tabular}

Source: own work

Table 2 shows the results of correlations between the variables analyzed in the study, used to test the first two hypotheses.

\section{Table 2}

Correlations between variables

\begin{tabular}{lccccc}
\hline 1. Career satisfaction & 1 & 2 & 3 & 4 & 5 \\
& 1 & & & & \\
$\begin{array}{l}\text { 2. Education-profile } \\
\text { setting }\end{array}$ & $0.32^{* *}$ & 1 & & & \\
$\begin{array}{l}\text { 3. Global satisfaction with } \\
\text { education }\end{array}$ & $0.41^{* *}$ & $0.64^{* *}$ & 1 & & \\
$\begin{array}{l}\text { 4. Guidance needs } \\
\text { S. Orientation process }\end{array}$ & $0.48^{* *}$ & $0.39^{* *}$ & $0.55^{* *}$ & 1 & \\
followed & $0.26^{* *}$ & $0.31^{* *}$ & $0.26^{* *}$ & $0.27^{* *}$ & 1 \\
\hline
\end{tabular}

Note. $* * \mathrm{p}<0.01$

Source: own work

In relation to the first hypothesis about the significant and positive relationship between satisfaction with career path, counseling needs, and counseling process, the relationship between satisfaction and career path and counseling needs obtained significant correlation $(\mathrm{r}=0.48, \mathrm{p}<$ 0.01 ).

In the questionnaire about counseling needs, high ratings in the answers corresponded to low needs, as high ratings meant participants had a number of aspects covered. The second part of the first hypothesis is also proved: there is a significant and positive relationship between satisfaction with career path and counseling process $(r=0.26, p<0.01)$. Therefore, the results obtained prove the first hypothesis.

Likewise, there is a significant, positive, and balanced relationship between global level of satisfaction with training/counseling and participant's profile $(\mathrm{r}=0.64, \mathrm{p}<0.01)$, so the second hypothesis in the study is also confirmed.

Finally, the third hypothesis had to do with the correlation between academic background and training/counseling needs. Figures $1 \mathrm{a}, 1 \mathrm{~b}$ and 1c show the boxplots for the three variables: counseling needs, career satisfaction, and lifelong guidance process. This figure illustrates the central tendency values, variability, and asymmetry and kurtosis. Parametric and nonparametric tests were carried out yielding similar results.

\section{Figure 1a}

Boxplots for the three variables: counseling needs.

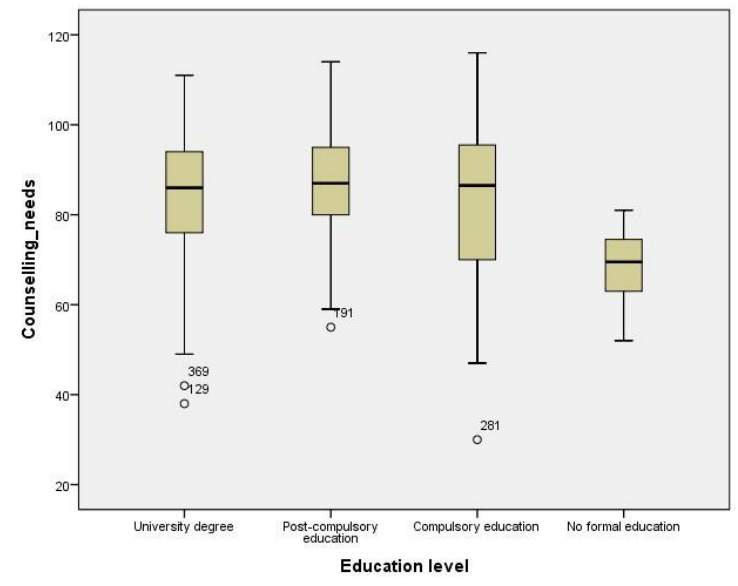

Figure 1b

Boxplots for the three variables career satisfaction

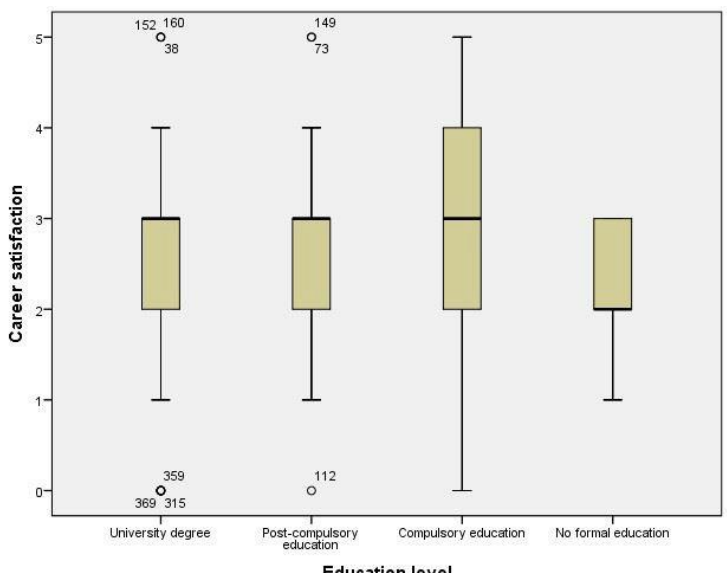

Source: own work 


\section{Figure 1c}

Boxplots for the three variables lifelong guidance process.

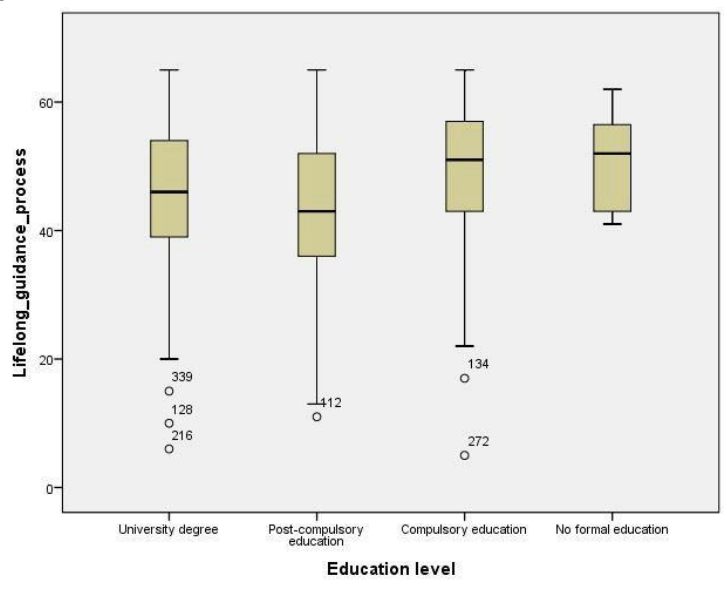

Source: own work

Table 3 shows the analysis of variance (ANOVA) for one factor, considering the highest education level and making distinctions between four groups: university, post-compulsory education, compulsory education, and no formal learning.

There were significant differences in the education, compulsory education, and no formal learning.

\section{Table 3}

Single factor ANOVA

\begin{tabular}{|c|c|c|c|c|c|c|c|}
\hline & & $\begin{array}{l}\text { Sum of } \\
\text { squares }\end{array}$ & $\mathrm{gl}$ & $\begin{array}{l}\text { Mean } \\
\text { Square }\end{array}$ & $\mathrm{F}$ & Sig. & $\eta^{2}$ \\
\hline \multirow{3}{*}{$\begin{array}{c}\text { Career } \\
\text { satisfaction }\end{array}$} & Inter-groups & 7.653 & 3 & 2.551 & 2.000 & 0.114 & \multirow[b]{3}{*}{0.016} \\
\hline & Intra-groups & 464.260 & 364 & 1.275 & & & \\
\hline & Total & 471.913 & 367 & & & & \\
\hline \multirow{2}{*}{$\begin{array}{l}\text { Counseling } \\
\text { needs }\end{array}$} & Inter-groups & 6078.228 & 3 & 2026.076 & 8.251 & $\begin{array}{l}0.000^{*} \\
*\end{array}$ & \multirow{3}{*}{0.071} \\
\hline & $\begin{array}{c}\text { Intra-groups } \\
\text { Total }\end{array}$ & $\begin{array}{l}79316.744 \\
85394.972\end{array}$ & $\begin{array}{l}323 \\
326\end{array}$ & 245.563 & & & \\
\hline $\begin{array}{l}\text { Lifelong } \\
\text { guidance }\end{array}$ & $\begin{array}{l}\text { Inter-groups } \\
\text { Intra-groups }\end{array}$ & $\begin{array}{c}1446.028 \\
39162.018\end{array}$ & $\begin{array}{c}3 \\
301\end{array}$ & $\begin{array}{l}482.009 \\
130.106\end{array}$ & 3.705 & $0.012^{*}$ & \\
\hline $\begin{array}{l}\text { process } \\
\text { followed }\end{array}$ & Total & 40608.046 & 304 & & & & 0.036 \\
\hline
\end{tabular}

Source: own work

There were significant differences in the variables of guidance needs $(\mathrm{F}=8.251, \mathrm{p}$ $\left.<0.01, h^{2}=0.071\right)$ and counseling process $\left(\mathrm{F}=3.705, \mathrm{p}<0.05, h^{2}=0.036\right)$. On the other hand, no significant differences were observed for general level of satisfaction with career path.

In order to analyze differences between groups, Levene's test was performed to check homogeneity of variance. As shown in Table
4, there was no equality of variances for counseling needs, so the Games-Howell procedure was carried out. On the other hand, the assumption of homoscedasticity applied to counseling process, so the Tukey range test was used in conjunction with it.

\section{Table 4}

\begin{tabular}{lcccc}
\hline & $\begin{array}{c}\text { Levene's } \\
\text { test }\end{array}$ & gl1 & gl2 & Sig. \\
\hline Career satisfaction & 2.248 & 3 & 364 & 0.082 \\
Guidance nceds & 4.875 & 3 & 323 & 0.002 \\
Orientation process followed & 1.902 & 3 & 301 & 0.129 \\
\hline
\end{tabular}

Source: own work

As shown in Table 5, participants without formal education had higher needs than participants in the other groups; this result backs up the third hypothesis in this study.

Finally, an in-depth analysis of the counseling process reveals a significant difference (Table 6) between participants with post-compulsory education and participants with compulsory education $(\mathrm{p}<$ 0.022 ) rather than between participants with no formal education and the other groups.

Table 5

Games Howell test for the variable needs guidance

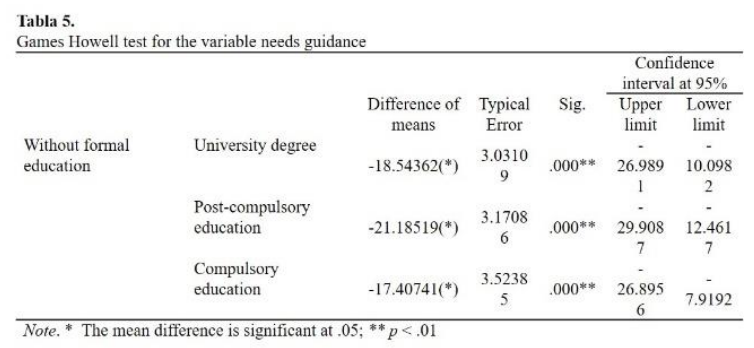

Source: own work

Table 6

Tukey test for the variable orientation process followed

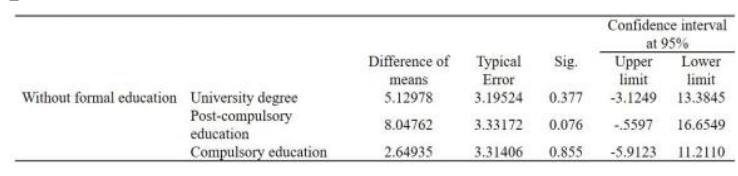

Source: own work

\section{Discussion}

The results obtained in this study revealed interesting facts about the counseling/training 
Measuring the relationship between career, guidance, and adults' training needs: Analysis and...

services offered by official employment agencies in the Spanish region of Castile and Leon. Furthermore, they are consistent with the research project they are part of: The guidance of the professional and vital project in the adult age: Analysis of needs, assessment of the employment services and identification of good practices.

Regarding the first hypothesis, it can be concluded that there is a significant and positive relationship between satisfaction and career path and counseling needs: the higher the level of satisfaction with one's career path, the lower the counseling needs as perceived by the user population.

Likewise, there is a significant and positive relationship too between satisfaction with career path and counseling process in guidance and training centres for employment.

In relation to the second hypothesis, results showed that there is a significant, positive and balanced relationship between global level of satisfaction, training/counseling, and participant's profile. This is self-evident in theory, but it is important that it is also true at the empirical level, the correlation between these two variables being the highest. This has important practical implications for guidance and training services, for they must make efforts to get balance between the contents of their training programmes and the profile of the participants.

Finally, participants in the study with no formal education have higher needs than those with compulsory, post-compulsory, or university education. This proves the third hypothesis. This result is relevant from the standpoint of social responsibility, revealing the importance of lifelong learning in accordance with the Recommendation of the European Parliament, the Council of December 18, 2006 on key competences for lifelong learning (2006/962/ EC), and with the Unesco World Conference for Higher Education (1998, 2009). On the other hand, no significant differences were found between groups with regard to counseling process except for a difference between participants with post-compulsory education and participants with compulsory education, which again underscores the need for balance between the contents of counseling and training programmes and the profile of the participant population.

The results obtained in this research are consistent with the social responsibility evaluation indicators (Club de Excelencia en Sostenibilidad, 2010): (1) adequate methodology, in line with ethical principles; (2) procedures to assess theme and method, adequacy of research, and educational projects to ethical principles; (3) percentage of research projects evaluated in accordance with the established ethical procedures; (4) research into subjects that brings scientifically grounded solutions to social issues affecting vulnerable sectors, thus contributing to the making of a more sustainable, more equal society; (5) curriculum contents and practices oriented toward original, relevant solutions to social issues, in the service of underprivileged groups; and (6) participation in experiences promoting cooperation and encouraging commitment in order to redress poverty, inequality, injustice, or social exclusion situations. As a matter of fact, participants face a series of difficulties when it comes to making career decisions, which are higher when they are at risk of poverty or social exclusion:

(...) based on irrelevant information, without planning skills that reveal the implications of the decisions made, or being conformist or dependent in the face of pressure from leading social actors, even discouraged to find their professional and training projects in life with responsibility. Their decisions are sometimes marked by the lack of professional guidance, or the lack or excess of information, so they are hasty, made with fear of being wrong, in sum, inadequate (Lucas, 2012, p. 487).

Concerning the limitations of this study, it should be mentioned that the analysis and the evaluation of results were based on self-report questionnaires and Likert-type scale answers. Although enriching (Martín et al., 2015; Zapata, 2005), the results are limited to the views of the broad and diverse population of participants. Besides, even when the sample is representative of the organisations and agencies offering employment, counseling, and training services, it 
could not be randomised.

On the basis of the results obtained, we can suggest a few lines for further research, for instance, a more specific study of the guidance and training needs for employment and career development of the population at risk of poverty or social exclusion, or the development of different counseling processes according to the educational background of the user population of career and employment counseling services. In this sense, a type of interview could be designed, applied, and evaluated to identify the training needs of the counseling staff working with groups at risk, for example, social or educational agents performing direct or indirect counseling tasks for employment or career development.

The results obtained with this research are an important reference in the design of an interview procedure for professionals working in the field of rural development, as well as social and educational agents carrying out, directly or indirectly, tasks and functions of employment counseling and guidance for career development (analysis of needs, assessment of employment services, and identification of best practices). The following questions derived from this research can be considered for an interview in further research and practice:

1. Among the tasks performed within the advisory function, what are the guidance needs detected in the population do you work with? Are there included some of the following needs? How far?

To favor a realistic and positive selfawareness, from the constructive management of feelings.

Motivation to encourage commitment from responsible risk-taking.

To meet the educational, training options and how to access to them.

Planning conflict resolution and autonomous and entrepreneurial decision-making.

2. Do you consider that existing resources to meet those needs are suitable (in number, approach, methodologies, etc.)? What weaknesses and threats do you consider that are more accessible in the design, implementation, evaluation, and follow-up counseling programs for employment and career development?

3. Do you perceive as an opportunity and strength to open a path of dialogue and cooperative work between schools and other agents and entities working in vocational guidance to insert these needs in a well articulated project in the curriculum? Do you have knowledge of how to do it? What proposals would you perform?

The information obtained though these questions enriches the knowledge of the user's profile; through guidance services for employment relevant and complete information is obtained, which facilitates the planning of individualized training itineraries as well as social and professional integration.

\section{Acknowledgement}

Project funded by the Spanish National R\&D\&I Project (Ref.: EDU2010-21873- C0301).

\section{References}

Bernal, A., \& Donoso, M. (2016). Estudio exploratorio para la creación de un cuestionario de evaluación de formación en emprendimiento social. [Exploratory study for the creation of an evaluation questionnaire on social entrepreneurship training]. Revista Científica Profesional de la Pedagogía y Psicopedagogía, Crónica 1 . 15-31.

Chen, C. P. (2010). Career meaning making: An essential in life. In M. McMahon \& M. Watson (Eds.), Career Counseling and Constructivism (pp. 39-55). New York: Nova Science Publishers, Inc.

Club de Excelencia en Sostenibilidad (2010). Una aproximación al estado de la Responsabilidad Social en la enseñanza en España [An approach to the state of Social Responsibilty in education in Spain]. Madrid: Ministerio de Trabajo e Inmigración. 
Guichard, J., Pouyaud, J., \& Dumora, B. (2010). Self-identity Construction and Reflexivity. In M. McMahon \& M. Watson (Eds.), Career Counseling and Constructivism (pp. 57-72). New York: Nova Science Publishers, Inc.

Little, B. R. (2006). Personality science and self-regulation: Personal projects as integrative units. Applied Psychology: An International Review, 55 (3), 419-427.

Lucas, S. (Octubre, 2009). Psicología social de la educación y desarrollo de competencias clave para el aprendizaje permanente: programas comunitarios de educación, formación $\mathrm{y}$ orientación professional [Social psychology of education and development of key competentes for permanent learning: communitary programmes of education, training, and career counseling]. In J. Tous \& J. M. Fabra (Eds.), Actas del XI Congreso Nacional de Psicología Social (pp. 556565). Tarragona: URV.

Lucas, S. (2012). Ética y construcción de toma de decisiones socialmente responsables (identidad personal, social y vocacional). Hacia una nueva teoría educativa y de investigación [Ethics and building of socially responsible decision making (vocational, social, and personal identity). Towards a new educational and investigation theory]. México: Lirio.

Lucas, S., \& Carbonero M. A. (2002). Construyendo la Decisión Vocacional [Building vocational decision]. Valladolid: Secretariado de Publicaciones e Intercambio Editorial, Universidad de Valladolid.

Martín, A., Lucas, S., \& Musitu, G. (2015). Programa de AprendizajeServicio y Responsabilidad Social en Educación Secundaria (PASRES). [Programme of Service-Learning and Social Responsibility in Secondary Education (PASRES)]. Madrid: Ministerio de Agricultura, Alimentación y Medio Ambiente.

McMahon, M., \& M. Watson (Eds.). (2010). Career Counseling and Constructivism. New York: Nova Science Publishers, Inc.
Mitchell, K. E., Levin, A. S., \& Krumboltz, J. D. (1999). Planned happenstance: Constructing unexpected career opportunities. Journal of Counseling and Development, 77, 115-124.

Osorio, J. L. (2014). La comunicación para el fomento de la cultura emprendedora entre la juventud. [Communication for the promotion of entrepreneurial culture among youth]. Málaga: Universidad de Málaga, Servicio de Publicaciones y Divulgación Científica. Retrieved from http://www.riuma.uma.es/xmlui/han dle/10630/8517

Padilla-Carmona, M. T., Sánchez-García, M. F., \& Suarez-Ortega, M. (2013, April). La orientación del proyecto vital $y$ professional en la edad adulta: Análisis de necesidades, valoración de servicios para el empleo e identificación de buenas prácticas [The guidance of the professional and vital project in the adult age: analysis of needs, assessment of the employment services and identification of good practices]. Paper presented at Jornadas Presenciales de Seguimiento Científico-Técnico de Proyectos de Investigación, Madrid.

Recomendación del Parlamento Europeo y del Consejo, de 18 de diciembre de 2006, sobre las competencias clave para el aprendizaje permanente (2006/962/ CE). (30 de diciembre de 2006) Diario Oficial de la Unión Europea, no L 394. Parlamento Europeo y Consejo de la Unión Europea. Retrieved from http://eurlex.europa.eu/LexUriServ/L exUriServ.do?uri=OJ:L:2006:394:0010:00 18:ES:PDF.

Romero, S. (2004). Aprender a construir proyectos profesionales y vitales [Learning how to build life and professional projects]. Revista Española de Orientación y Psicopedagogía, 15, 2, 337-354.

Savickas, M. L. (1997). Career adaptability: An integrative construct for life span, life space theory. The Career Development Quarterly , 45, 246-259.

Savickas, M. L., Nota, L., Rossier, J., Dauwalder, 
Enrique Merino Tejedor, Susana Lucas Mangas, Jesús Boyano Sierra.

J. P., Duarte, M. E., Guichard, J.,... van Vianen, A. E. M. (2009). Life designing: A paradigm for career construction in the 21st century. Journal of Vocational Behavior, 75, 239-250.

Steger, M. F., \& Dik, B. J. (2009). If one is looking for meaning in life, does it help to find meaning in work? Applied Psychology: Health and Well-being, 1 (3), 303-320.

Unesco (1998). Declaración Mundial sobre la Educación Superior en el Siglo XXI: Visión y Acción. Retrieved from http://www.unesco.org/education/ed ucprog/wche/declaration_spa.htm

Unesco (2009). Comunicado de la

Conferencia Mundial sobre la Educación Superior-2009: La nueva dinámica de la Educación Superior y la investigación para el cambio social y el desarrollo. París, 5-8 de julio de 2009. Retrieved from http://www.unesco.org/education/W CHE2009/comunicado_es.pdf

Zapata, O. (2005). La aventura del pensamiento crítico: Herramientas para elaborar tesis $e$ investigaciones socioeducativas [The adventure of critical thinking: Tools for carry out socio-educational thesis and research]. México D.F.: Pax México.

\section{Notes}

* Research article. Partner agencies: Ministry of Science and Innovation (Government of Spain) on the 2010 call (reference: EDU2010-21873-C03-01). 